\title{
Contrasting metamorphism across Cauvery Shear Zone, south India
}

\author{
Manish M John, S BALAKRIShnan* and B K BhADRA** \\ Department of Earth Sciences, Pondicherry University, Pondicherry 605 014, India. \\ *e-mail: sbala_2002@yahoo.com \\ ** Present address: RRSSC/ISRO, CAZRI Campus, Jodhpur 3, Rajasthan, India.
}

The Palghat Cauvery Shear Zone (CSZ) is a major shear zone that possibly extends into different fragments of Gondwanaland. In the present study mafic granulites occurring on either side of the CSZ in Namakkal area, southern India are examined. Textural features recorded in the mafic granulites are crucial in elucidating the metamorphic history of the southern granulite terrane (SGT).

In the mafic granulites occurring to the south of CSZ, evidence of garnet breaking down during near isothermal decompression (ITD) is indicated by the development of orthopyroxene + plagioclase moats in between quartz and garnet. The presence of comparatively small elongated second generation garnet embedded in pyroxenes from the mafic granulites occurring to the north of CSZ is indicative of the garnet formation via reaction between pyroxenes and plagioclase, which occurred during isobaric cooling (IBC).

Rocks occurring to the south of CSZ have recorded comparatively higher temperature and pressure $\left(849^{\circ} \mathrm{C}\right.$ and $\left.9.6 \mathrm{kbar}\right)$ than those occurring to the north of the $\mathrm{CSZ}\left(731^{\circ} \mathrm{C}\right.$ and $\left.8.6 \mathrm{kbar}\right)$ using conventional geothermobarometry. The rocks occurring to the north of CSZ have suffered more complex metamorphic histories in comparison to the southern part. Integrating the results of the present field and metamorphic studies with the earlier investigations and available geochronological data we suggest that the CSZ could represent a suture zone between two different continental blocks that underwent distinct metamorphic evolution.

\section{Introduction}

Granulites are the high grade metamorphic rocks that originate in the lower to mid continental crust. Their exhumation may occur through later tectonic events either related or unrelated to their formation. The study of already exposed granulites includes careful examination of mineral assemblages and textures, as well as, estimation of the paleo pressure and temperature conditions which helps in understanding deep crustal processes. Based on such a study $\mathrm{P}-\mathrm{T}-\mathrm{t}$ path (pressure and temperature variation with time) could be determined (Harley 1989) and constraints can be placed on various models proposed for the origin of granulites.

South Indian granulite terrane was part of Gondwanaland, and thus petrological studies on this terrane have an important bearing in understanding the Precambrian evolutionary history of the Gondwanaland. The amalgamation of Gondwanaland has generally been regarded to have occurred some time around 500-550 Ma (McWilliams 1981; Unrug 1996) and pre-Pan-African signatures of south India, Madagascar and Sri Lanka are fundamentally important to characterize the amalgamation tectonics (Janardhan 1999b; Yoshida et al 1999). The Archaean terranes in both Madagascar and

Keywords. Cauvery Shear Zone; granulites; geothermobarometry; south India; Gondwanaland. 
Dharwar craton are characterized by $\mathrm{N}-\mathrm{S}$ trending greenstone belts occurring within the gneissose granitic rocks in the northern part. Major shear zones in these continental fragments are expected to play a critical role in their correlation. Detailed elucidation of the metamorphic history and tectonics of rocks on either side of any one of the major shear zones would also provide important constraints on various models for the evolution of the Gondwanaland.

The Cauvery Shear Zone (CSZ) is an E-W trending $600 \mathrm{~km}$ long crustal scale tectonic feature, initially demarcated by Drury et al (1984) using satellite imagery. It divides southern Peninsular India into two major blocks viz., northern and southern blocks. The northern block is mainly composed of mafic granulites and charnockites, in contrast the southern block is made up of pelitic and calc granulites with profuse intrusion of late Proterozoic granites of Pan-African age (Raith et al 1990; Mohan and Windley 1993; Janardhan et al 1996).

The northern granulite block includes the Coorg-Niligiri-BR Hills-Salem-Madras blocks and had witnessed a 2500 Ma old (late Archaean) granulite metamorphism (Raith et al 1990; Janardhan et al 1994, 1996; Srikantappa 1996). Thermobarometric and metamorphic textural studies of Nilgiri and Coorg rocks indicate an over-all anticlockwise P-T path (Srikantappa et al 1988; Raith et al 1990; Devaraju and Janardhan 2004) for the northern block and can be stated to be made up of two components, an earlier isobaric cooling (IBC) with a slightly later isothermal decompression (ITD) paths (Janardhan et al 1982; Frost and Chacko 1989; Janardhan and Shankara 1995; Srikantappa 1996).

In contrast, the southern granulite block comprising of Kodaikanal-Madurai-Trivandrum and Nagercoil blocks record an imprint of $550 \mathrm{Ma}$ old (Pan-African) granulite metamorphism. Thermobarometric determinations and textural studies on Kodaikanal range granulites (Wiebe and Janardhan 1988; Frost and Chacko 1989; Mohan et al 1996), mafic granulites and the metapelites from the Palghat gap (Ravindrakumar and Chacko 1994) and sapphirine-bearing granulites from Ganguvarpatti (Mohan and Windley 1993) suggested an over-all clockwise path dominated by ITD component with a steep drop in pressure.

There appears a distinct difference in the $\mathrm{P}-\mathrm{T}-\mathrm{t}$ paths of granulites occurring on either side of the CSZ. However, the above mentioned granulite rocks crop out several hundreds of $\mathrm{km}$ to north and south of the Cauvery Shear Zone (Drury et al 1984; Chetty 1996; Ghosh 1997; Mukhopadhyay et al 2000). It is not clear whether the CSZ divides a single block into two or it represents a suture between two granulite terranes with distinct evolutionary histories. A detailed textural and $\mathrm{P}-\mathrm{T}-\mathrm{t}$ study of rocks occurring on either side of the shear zone of the Namakkal area has been attempted to understand its significance and relevance to the tectonic evolution of the area.

\section{Geology of the area}

The present study area is situated south of Namakkal comprising a segment in the eastern part of the CSZ (figure 1a). Here, the CSZ is marked by the presence of $2-3 \mathrm{~km}$ wide $\mathrm{E}-\mathrm{W}$ trending mylonitic (augen) gneisses, which are composed of augen shaped quartz and feldspar grains and also consist of mica and hornblende, situated on the northern bank of the Cauvery river (figure 1b). Mafic granulite and granite migmatites occur on the northern part of the CSZ while granitic gneisses constitute the southern part. Mafic granulites usually occur as variably sized enclaves within the granitic gneisses of the south. Hornblende biotite gneiss occurs as a thin band sub-parallel to CSZ in the northern part.

Mukhopadhyay et al (2000) have also reported the presence of mafic granulites, enderbitic gneisses and garnetiferous quartzo-feldspathic gneisses from the same area. According to them, this region is characterized by the presence of several mapable mafic granulite bands in a terrane of garnetiferous enderbite and quartzo-feldspathic gneiss. Thin bands of BIF are present within the enderbitic gneisses. The garnetiferous quartzo-feldspathic gneisses show intrusive relationship with both the enderbites and the mafic granulites.

To the north of shear zone, mafic granulites are composed of clinopyroxenes, orthopyroxenes, hornblende and plagioclase with a fair amount of garnet and little mica (mainly biotite). Granite migmatite shows alternative layers of melanocratic (composed of hornblende and biotite) and leucocratic layers (composed of quartz and feldspar).

Granite gneiss occurring to the south of CSZ is more or less pink in color showing distinct gneissic structure composed of quartz, feldspar and little garnet and needle shaped hornblende and biotites.

On either side of the shear zone, the rocks are relatively undeformed and characterized by granulite facies metamorphism. But within the shear zone the rocks are extensively deformed giving rise to penetrative planar and linear structures and have undergone extensive retrogression. Rocks also show varying degrees of mylonitisation and migmatisation. Mukhopadhyay et al (2000) observed that at many localities a mylonitic foliation parallel to the gniessosity was developed in thin felsic bands found 


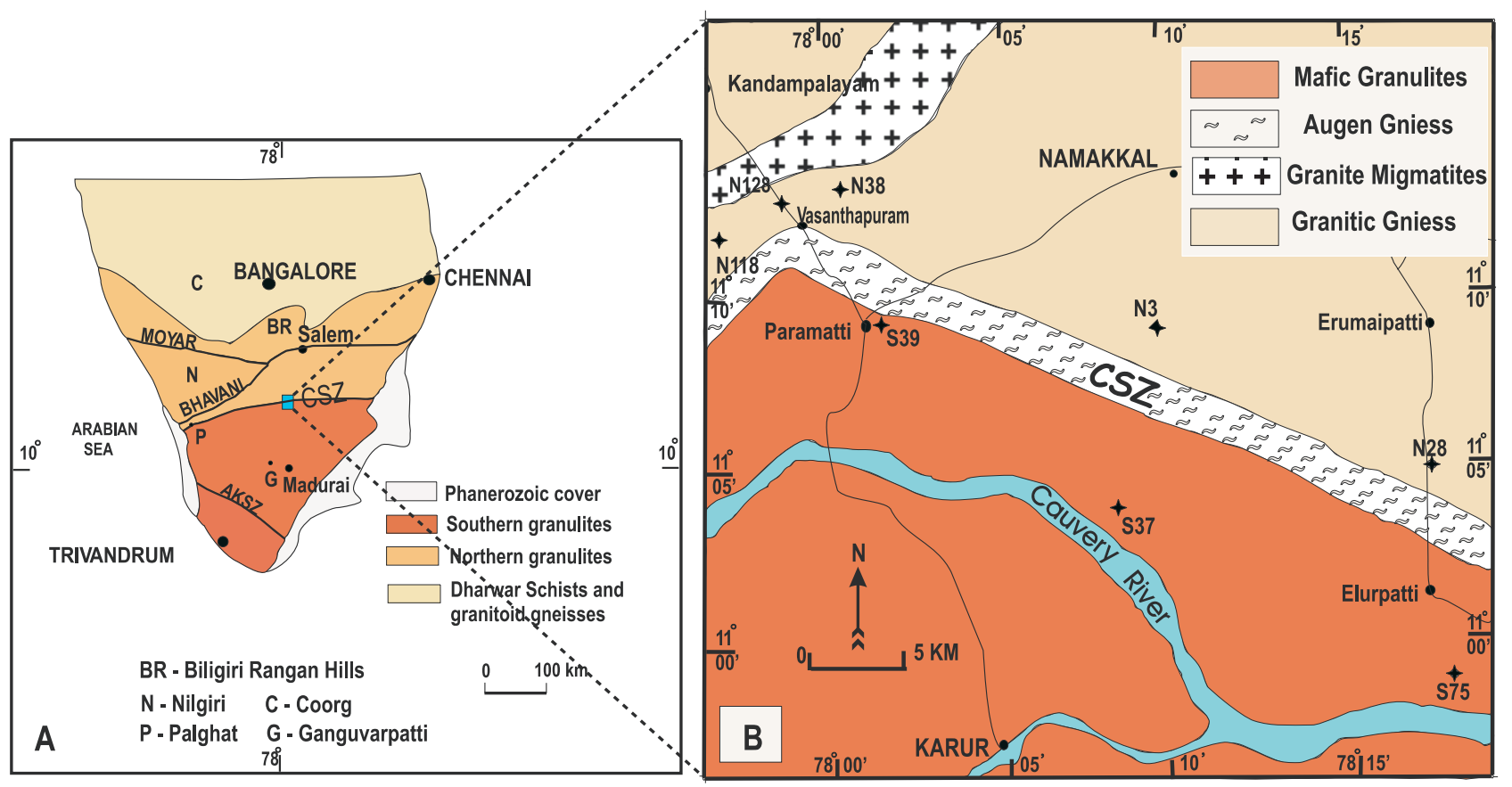

Figure 1. (A) Geological map of southern granulite terrane indicating Moyar, Bhavani, Palghat-Cauvery (CSZ) and Achan Kovil Shear Zones (AKSZ) and the study area. (B) Geological map of the Namakkal area where the augen gneisses define the CSZ. The CSZ is sub-parallel to the Cauvery river and it takes a southwesterly turn near Vasanthapuram. The sample locations are numbered.

within the mafic granulites. Bhadra (1999) found that in the eastern part of CSZ, shear zone rocks are essentially mylonites showing all the effects of ductile shearing, whereas, in the western part, the rocks are dominantly augen gneisses. This may be related to the variation in the shearing intensity or due to oblique shearing.

Ghosh (1997) showed three progressive shearing events viz. $\mathrm{D}_{1}$ (dextral), $\mathrm{D}_{2}$ (sinistral) and $\mathrm{D}_{3}$ (dextral) along the CSZ between Salem and Karur. Among the three different phases of shearing the dextral phases are very widespread. According to Mukhopadhyay et al (2000) the shear zones are mostly of oblique slip nature as revealed by the moderate to high pitch of slickenlines and the horizontal component has commonly a dextral shear sense. Kinematic analysis from these shear sense indicators in the study area also show an over-all dextral sense of movement.

Other than Cauvery Shear Zone, another shear zone has also been identified in the study area which is less deformed and trending NE-SW and is possibly a part of $\mathrm{N} 45^{\circ} \mathrm{E}$ fault zone and is characterized by migmatites. It is noticeable that Cauvery Shear Zone takes a $90^{\circ}$ turn southwest of Paramatti (figure 1b) and the reason for the bending is not known. Samples of mafic granulites with suitable mineral assemblages have been collected from outcrops on either side of the CSZ.

\section{Petrography}

\subsection{South of Cauvery Shear Zone}

In the terrane occurring south of the CSZ, both moat and corona textures are present. Mainly two textural forms of garnets are present. The most common form is larger, porphyroblastic grains which at places contain clinopyroxene, orthopyroxene, hornblende, plagioclase and quartz inclusions. The second form is garnet beads or blebs which rim around plagioclase, hornblende and/or orthopyroxene. The following garnet forming prograde metamorphic reactions explain the textural evolution:

$$
\begin{aligned}
& \text { Hornblende }+ \text { plagioclase }+ \text { quartz garnet } \\
& + \text { clinopyroxene }+\mathrm{V},
\end{aligned}
$$

$$
\text { Plagioclase }+ \text { hornblende }+ \text { magnetite }+ \text { quartz }
$$$$
\rightarrow \text { garnet }+ \text { clinopyroxene }+\mathrm{H}_{2} \mathrm{O}+\mathrm{O}_{2} \text {. }
$$

Two textural varities of hornblende are also observed in the southern mafic granulites. A coarse grained variety of hornblende co-exists with the coarse grained pyroxene, suggesting that they are part of the primary mineral phases. The coarse grained hornblende and the one occurring as inclusion in the garnet are of the same generation as they have similar optical characteristics. Both 
these varieties of hornblende are part of the prograde mineral assemblages. The second generation of hornblende occurs as symplectite along with clinopyroxene and plagioclase and forms a thin corona around the garnet.

Garnet breakdown to plagioclase and orthopyroxene/clinopyroxene characterizes decompression via the following reactions:

$$
\begin{gathered}
\text { Garnet }+ \text { quartz } \rightarrow \text { orthopyroxene } \\
+ \text { plagioclase (Harley 1989) }
\end{gathered}
$$

$$
\begin{aligned}
& \text { Garnet }+ \text { quartz } \pm \mathrm{O}_{2} \rightarrow \text { orthopyroxene } \\
& + \text { plagioclase } \pm \text { magnetite }
\end{aligned}
$$

$$
\begin{aligned}
& \text { Garnet }+ \text { quartz } \rightarrow \text { clinopyroxene } \\
& \quad+\text { plagioclase (Mengel and Rivers 1991) }
\end{aligned}
$$

Formation of plagioclase corona around garnet at the contact of clinopyroxene/hornblende also attests decompressional reaction texture via reactions:

$$
\begin{aligned}
& \text { Garnet }+ \text { clinopyroxene }+ \text { quartz } \\
& \quad \rightarrow \text { orthopyroxene }+ \text { plagioclase }, \\
& \text { Garnet }+ \text { amphibole }( \pm \text { clinopyroxene }) \\
& \quad \rightarrow \text { orthopyroxene }+ \text { plagioclase }+\mathrm{V} \text {. }
\end{aligned}
$$

Reactions (6 and 7) also result in the formation of an orthopyroxene rim around clinopyroxene/ amphibole. Similarly, the formation of plagioclasehornblende symplectite with or without magnetite (figure $2 \mathrm{~b}$ ) suggests the following reaction:

$$
\begin{aligned}
& \text { Garnet }+ \text { clinopyroxene }+ \text { quartz }+\mathrm{V} \\
& \quad \rightarrow \text { plagioclase }+ \text { hornblende } \pm \text { magnetite }
\end{aligned}
$$

Garnet breaking down during retrogression (decompression) is indicated by the development of orthopyroxene+plagioclase moats in between quartz and garnet (figure $2 \mathrm{a}$ and b). Harley (1989) has shown that this texture is indicative of isothermal decompression rather than isobaric cooling. Ravindrakumar and Chacko (1994) have also reported the formation of orthopyroxene+ plagioclase symplectite from granulites of Palghat area (a part of Kodaikanal ridge) and interpreted that they have undergone a steep near isothermal decompression. Thus, the southern mafic granulites show evidence of attaining first peak pressure followed by peak temperature and retrograde reactions taking place with decreasing pressure at nearly isothermal conditions. These textures are
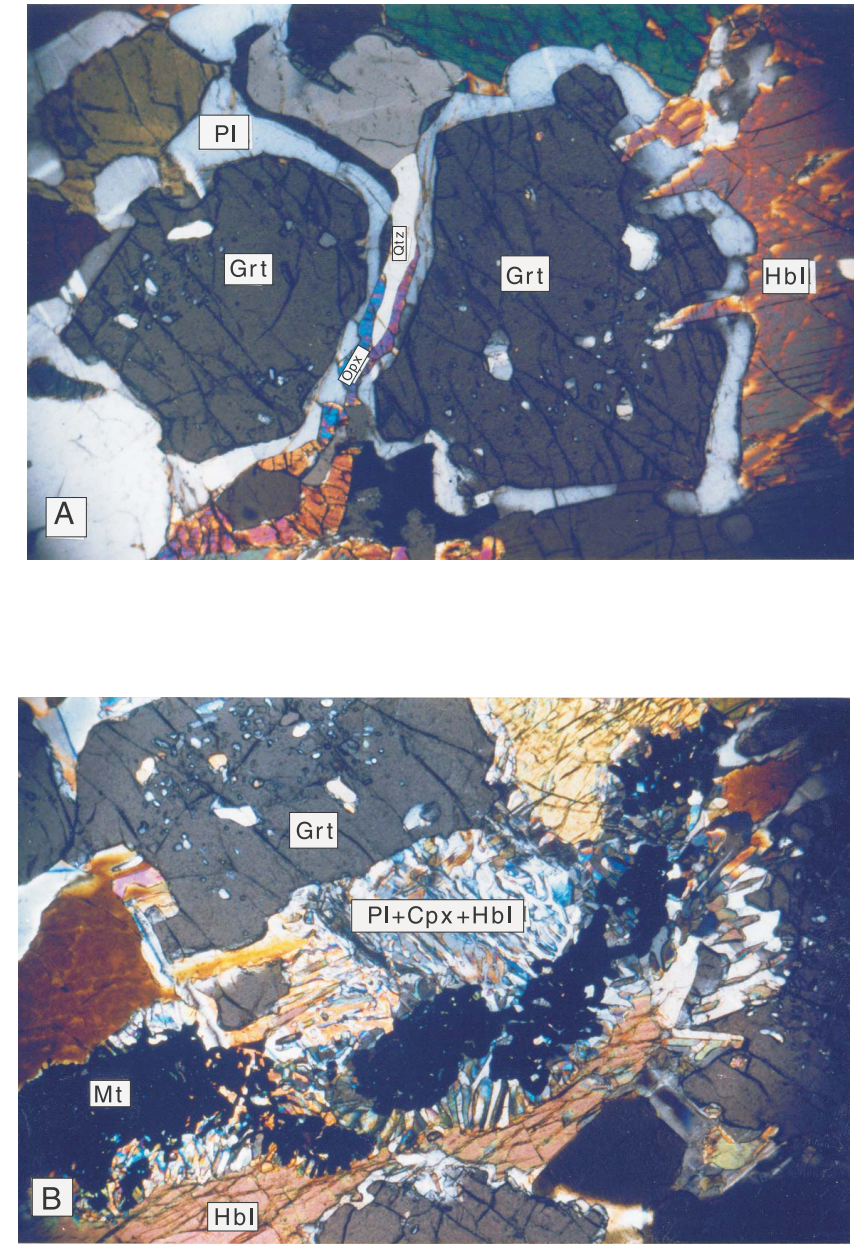

Figure 2. Reaction textures observed in mafic granulites occurring south of CSZ (samples S75 and S37). Width of the photomicrograph is indicated in square brackets. (A) Garnet formed during the prograde metamorphism is broken down into plagioclase and orthopyroxene which form corona around it. Hornblende projects into garnet cutting across the plagioclase rim near the right-hand edge of the photo [3.0 mm]. (B) Shows formation of plagioclase, hornblende and clinopyroxene symplectite with or without magnetite. Both the textures are developed during retrograde metamorphism involving isothermal decompression [2.1 $\mathrm{mm}]$.

suggestive of a clockwise $\mathrm{P}-\mathrm{T}-\mathrm{t}$ path for the evolution of granulites occurring south of CSZ.

\subsection{North of Cauvery Shear Zone}

In the terrane occurring north of CSZ, mafic granulites show granoblastic mosaic texture which is given by clinopyroxene/orthopyroxene, hornblende, garnet and plagioclase. Garnet porphyroblasts are generally globular in shape and contain clinopyroxene, plagioclase and hornblende inclusions which are primary metamorphic mineral reactants. This suggests the following prograde metamorphic reactions: 
Hornblende + plagioclase + quartz

$$
\rightarrow \text { clinopyroxene }+ \text { garnet }+\mathrm{V},
$$

Clinopyroxene + plagioclase $\rightarrow$ garnet + quartz.

The porphyroblastic globular garnets formed by the above reactions 9 and 10 are rimmed by fine grained orthopyroxene, clinopyroxene, plagioclase and garnet thus showing coronitic texture (figure 3a). On this basis, the following retrograde (decompressional) reactions have been inferred to have taken place. (Suffix 1 and 2 indicate 1st and 2nd generation minerals.)

Garnet $_{1}+$ clinopyroxene $_{1}+$ quartz

$\rightarrow$ orthopyroxene $_{2}+$ plagioclase $_{2}$,

Garnet $_{1}+$ clinopyroxene $_{1}+$ quartz

$\rightarrow$ clinopyroxene $_{2}+$ plagioclase $_{2}$

\pm orthopyroxene $_{2}$,

Garnet $_{1}+$ clinopyroxene $_{1}+$ plagioclase $_{1}+$ quartz

$+\mathrm{H}_{2} \mathrm{O}+\mathrm{O}_{2} \rightarrow$ garnet $_{2}+$ plagioclase $_{2}$

+ hornblende $_{2}+$ magnetite,

Garnet $_{1}+$ plagioclase $_{1}+$ quartz + biotite $+\mathrm{H}_{2} \mathrm{O}$

$\rightarrow$ plagioclase $_{2}+$ garnet $_{2}+$ orthopyroxene $_{2}$

+ K-feldspar ${ }_{2}+$ hornblende $_{2}+\mathrm{V}$.

The presence of retrograde hornblende around clinopyroxene suggest the following reaction:

Orthopyroxene + clinopyroxene + plagioclase

$\rightarrow$ hornblende + quartz.

The first generation garnets are rich in inclusions and comparatively pale gray in colour under microscope, whereas the second generation garnets are pinkish in colour. The first generation garnets have slightly higher $\mathrm{X}_{\mathrm{Mg}}$ values $(0.28)$ relative to the second generation garnet $(0.26)$. The presence of comparatively small elongated second generation garnets embedded in clinopyroxene (figure $3 \mathrm{~b}$ ) suggest the garnet formation by the reaction:

Clinopyroxene + plagioclase $\rightarrow$ garnet $_{2}+$ quartz
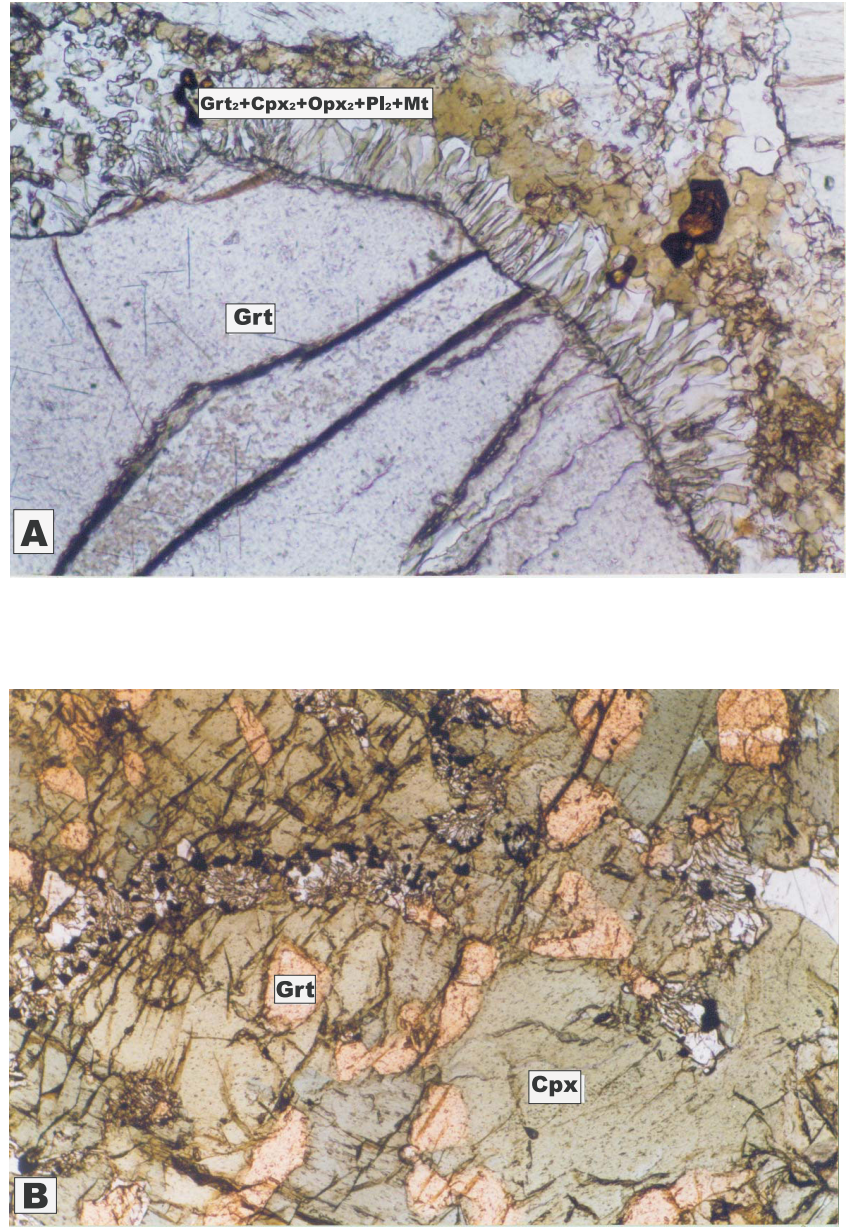

Figure 3. Photomicrographs of reaction textures observed in mafic granulites occurring north of CSZ (samples N3 and N128). Width of the photomicrograph is indicated in square brackets. (A) Coronitic texture, given by orthopyroxene, clinopyroxene, plagioclase and garnet around the prograde garnet $[0.525 \mathrm{~mm}]$. (B) Presence of comparatively small elongated second generation garnet embedded in clinopyroxene. Both the textures are indicative of isobaric cooling during retrograde metamorphism $[2.1 \mathrm{~mm}]$.

The above reaction is indicative of isobaric cooling as suggested by Harley (1989). Development of second generation garnet grains from the first generation garnet grains also points towards isobaric cooling. Hence compared to the southern part, mafic granulites of the northern part have the textural evidence of both isothermal decompression and isobaric cooling. Nilgiri granulites also show a similar retrograde reaction texture involving the formation of garnet+quartz coronas around pyroxene grains (Raith et al 1990). But textural evidences of isothermal decompression during retrogression also exist in the presence of the coronitic texture given by orthopyroxene ${ }_{2}$, clinopyroxene ${ }_{2}$, and plagioclase ${ }_{2}$ around the garnet $_{1}$ which has the relict inclusions of pyroxene ${ }_{1}$ and plagioclase . $_{1}$. Hence the northern part is comparatively more complex and might have undergone one or more 

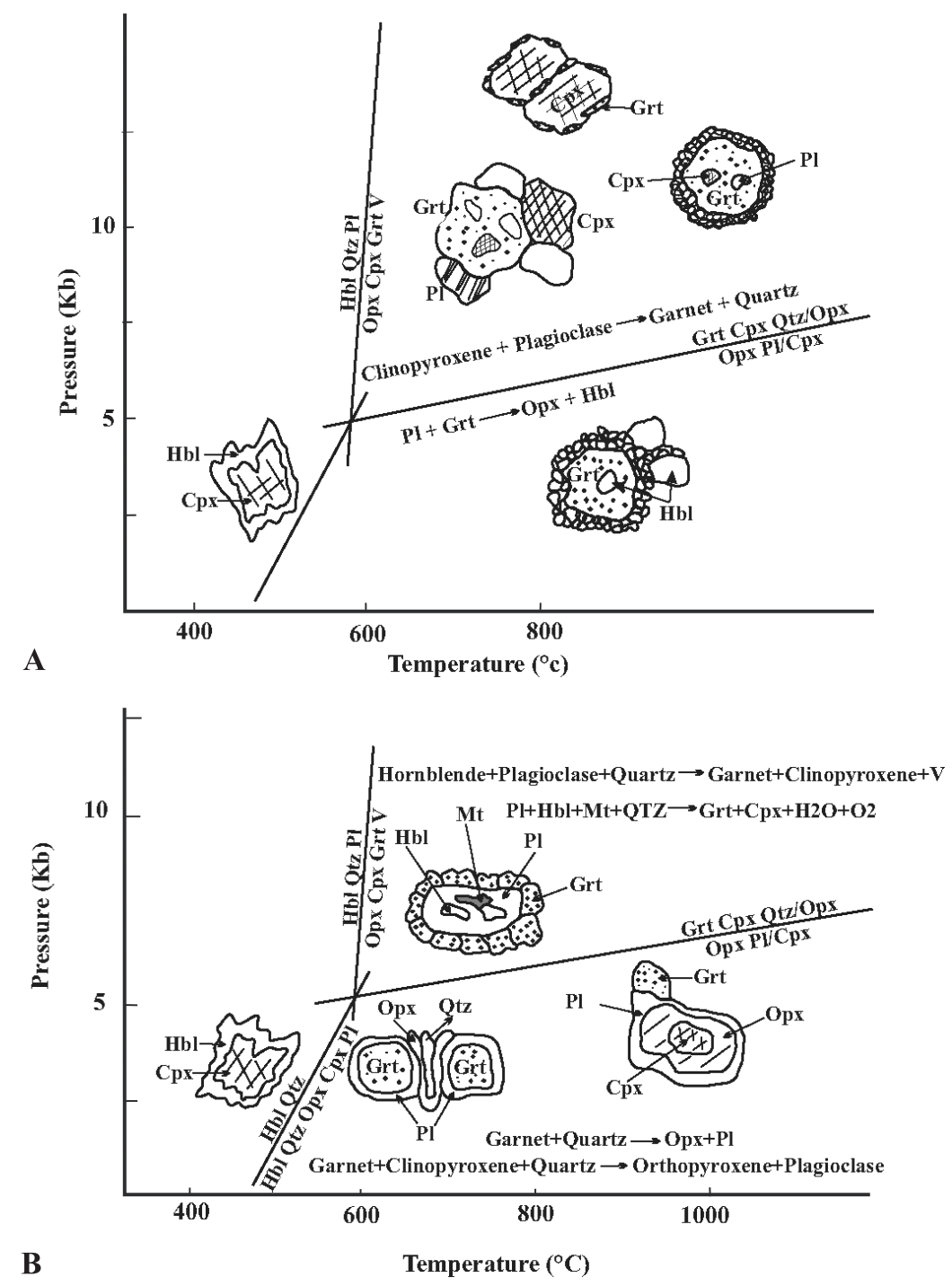

Figure 4. Schematic representations of textures present in the mafic granulites occurring to north and south of CSZ in the Namkkal area. (A) Northern part is more complex with evidences of both IBC and ITD paths, whereas (B) southern part shows only ITD path. $(\mathrm{Pl}=$ plagioclase, $\mathrm{Qtz}=$ quartz, $\mathrm{Hbl}=$ hornblende, $\mathrm{Cpx}=$ clinopyroxene, Opx $=$ orthopyroxene, $\mathrm{Mt}=$ magnetite, $\mathrm{Grt}=$ garnet, $\mathrm{V}=$ volatiles $)$.

stages of metamorphism. It is noted that garnet embedded clinopyroxenes are cut by fractures formed due to deformation (pre-shear) and are thus inferred to have crystallized before the deformation.

In nature, $\mathrm{P}-\mathrm{T}-\mathrm{t}$ paths are often more complex and may represent a combination of both ITD and IBC, such as an initial IBC followed by ITD (or vice versa) in a single cycle or even in multiple stages (Passchier and Trouw 1996). Schematic diagrams of these reaction textures observed in the granulites occurring to north and south of CSZ are represented in figure 4a and b respectively. Assuming that the mineral assemblages and textures observed were developed in a single metamorphic cycle, an isothermal decompressional (ITD, clockwise) path is inferred for the southern granulites (figure 4b). On the contrary the northern granulites showing evidences for both IBC and ITD paths, could have evolved in multiple stages (figure 4a).

\section{Mineral chemistry}

Mineral analyses were carried out on an $\mathrm{S} \times 50$ Cameca electron microprobe at the Department of Geology, University of Mysore using a wavelength dispersive analysis system. Pure oxides and natural minerals were used as standards during the analysis and the mineral analyses data are given in table 1. Most of the garnet grains on both sides of the CSZ are closer to the almandine-pyrope-grossular type. In the southern part $(\mathrm{Fe} / \mathrm{Fe}+\mathrm{Mg}+\mathrm{Mn}+\mathrm{Ca})$ values 


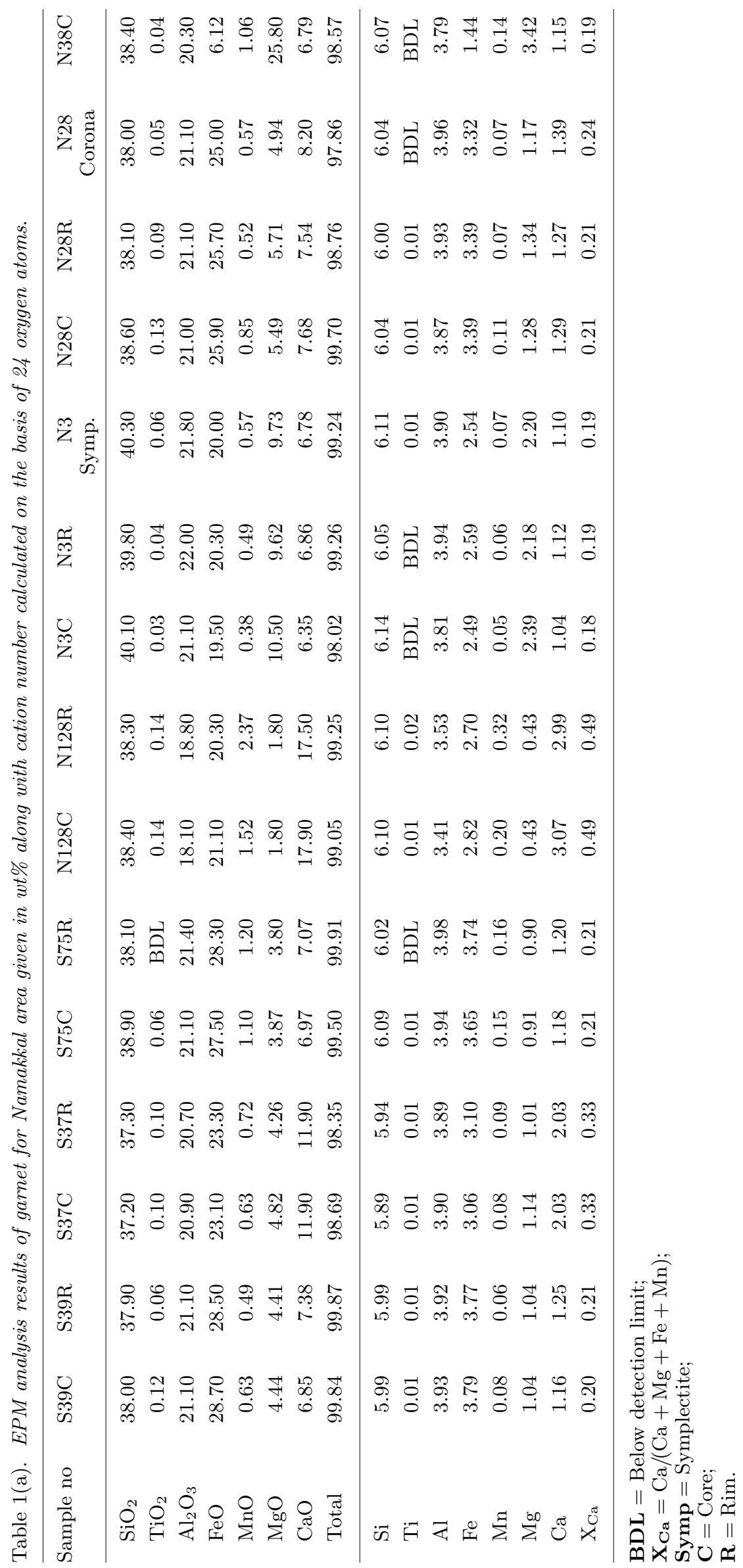




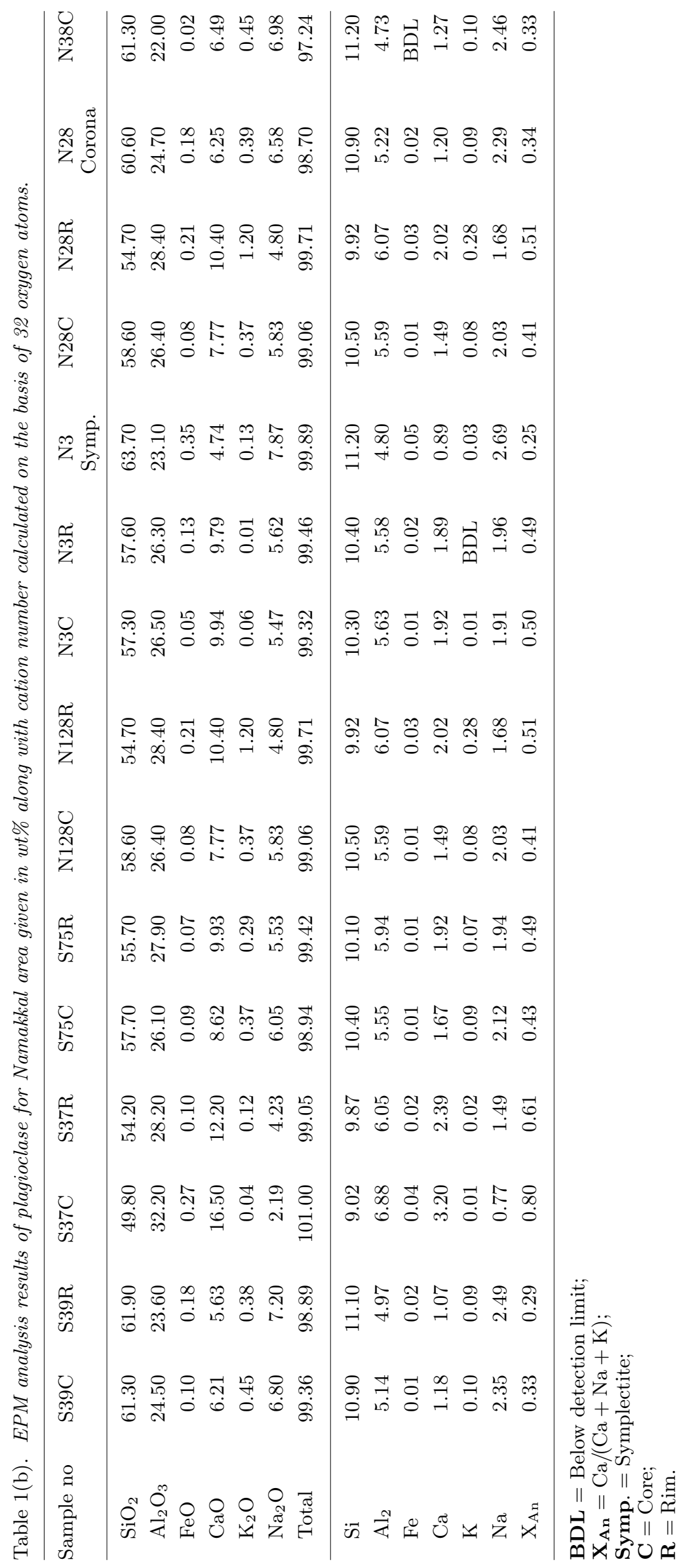




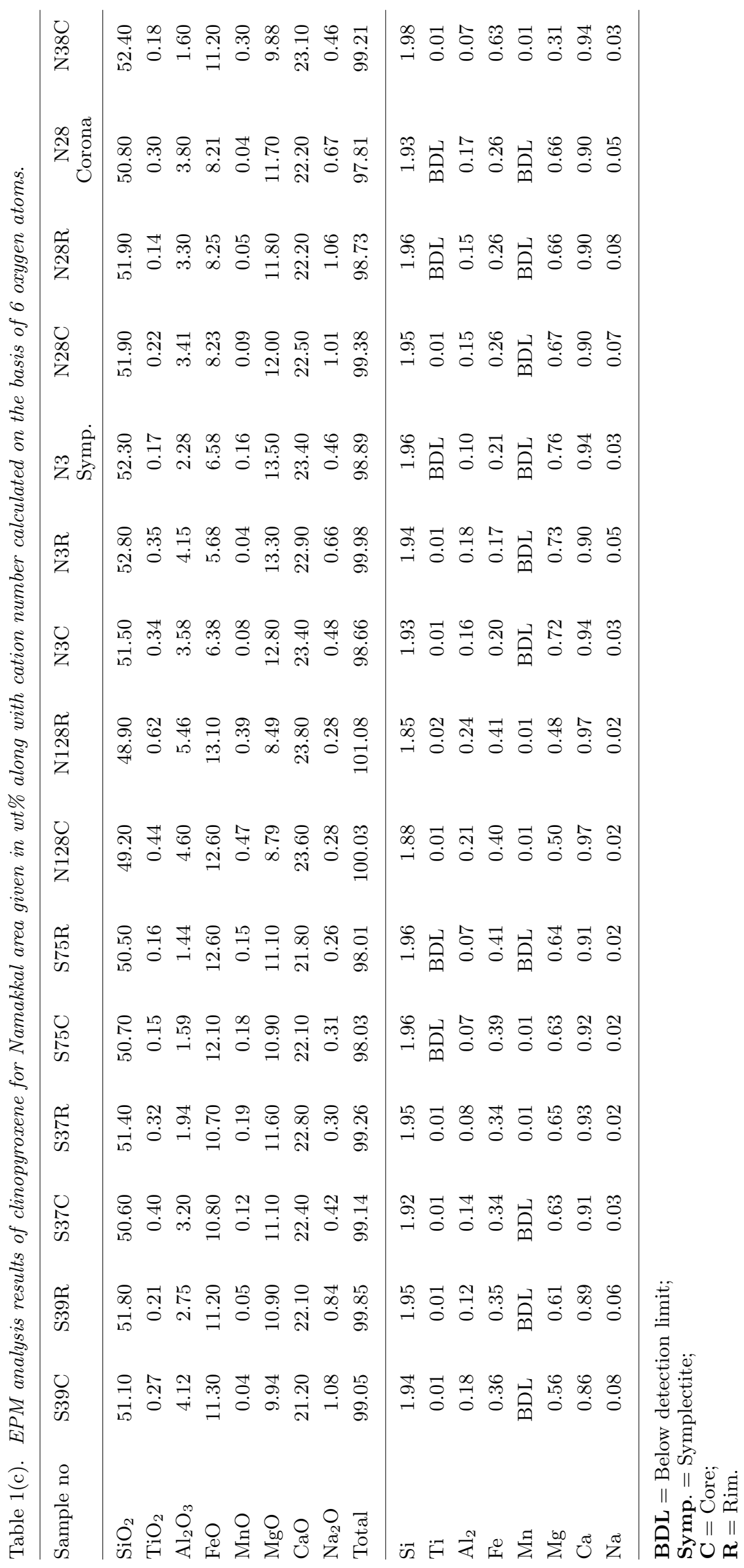




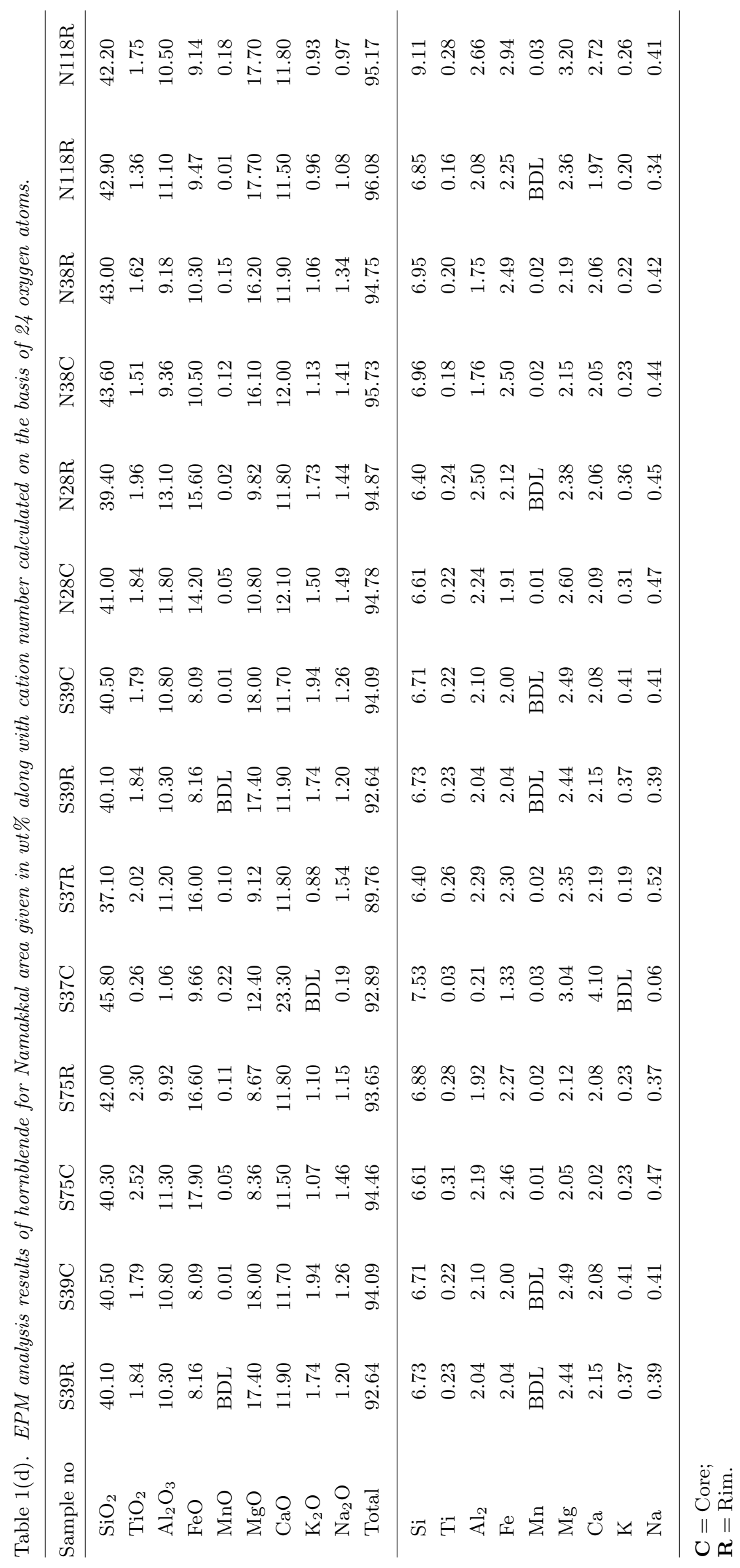




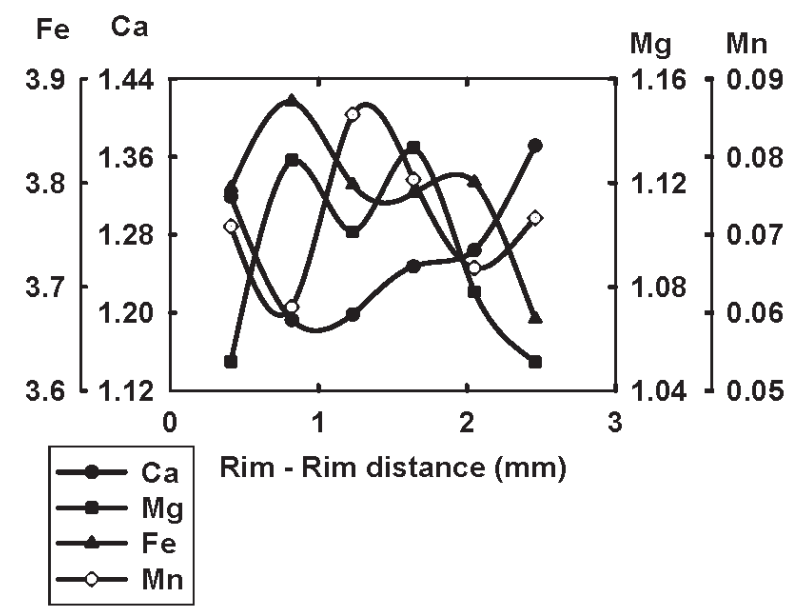

Figure 5. Variations of abundances of $\mathrm{Mg}, \mathrm{Fe}, \mathrm{Ca}$, and $\mathrm{Mn}$ cations across a garnet grain for the sample S39 occurring just south of the CSZ.

range from 0.62 (Pyrope 20-30), for samples S39 and S75 and 0.49 for sample S37. Whereas, in the northern part values are 0.42 for samples N3 and N128 and 0.56 for samples N28 and N38. Cores of the garnet grains from sample \#N3 and S37 have relatively high $\mathrm{Mg}$ values than the rim. $\mathrm{Mg}$ abundance is directly proportional while grossular and almandine contents are inversely proportional to temperature and pressure. $K_{D}$ values of the garnet-clinopyroxene thermometer calculated for basic granulites occurring on either side of the shear zone ranges from 4 to 7 .

Core and rim spot analysis have been carried out in order to assess the degree of compositional variation. Variations of $\mathrm{Ca}, \mathrm{Mg}, \mathrm{Fe}$ and $\mathrm{Mn}$ across the garnet grains from either side of CSZ are examined and one of the garnets from the south is given in figure 5. On both sides of the CSZ, Ca and Mg show opposite trends of abundance across the grain and have comparatively higher abundance of $\mathrm{Mg}$ in the core than the rim. But one sample of the northern part which has a hornblende inclusion in the centre shows a decrease in the $\mathrm{Mg}$ abundance from the rim to core. For this sample temperature estimated for the rim is comparatively higher than the core.

Amphiboles of three samples occurring south of CSZ are classified as hornblende on the basis of $(\mathrm{Na}+\mathrm{K})$ vs. Si diagram plotted for amphiboles to recognize the compositional range. Except these all other samples from both sides of CSZ fall in the edinitic compositional region. All amphiboles analyzed show a very good negative correlation between $\mathrm{Al}^{\mathrm{iv}}$ and $\mathrm{Si}$ (figure 6a) indicating $\mathrm{Al}$ substitution for Si. Al substitution could be accompanied by alkali ions like $\mathrm{K}^{+}$and $\mathrm{Na}^{+}$entering the 'A' site of amphiboles. The southern samples show a positive correlation in the plot $(\mathrm{Na}+\mathrm{K})$ vs. $\mathrm{Al}^{\mathrm{iv}}$

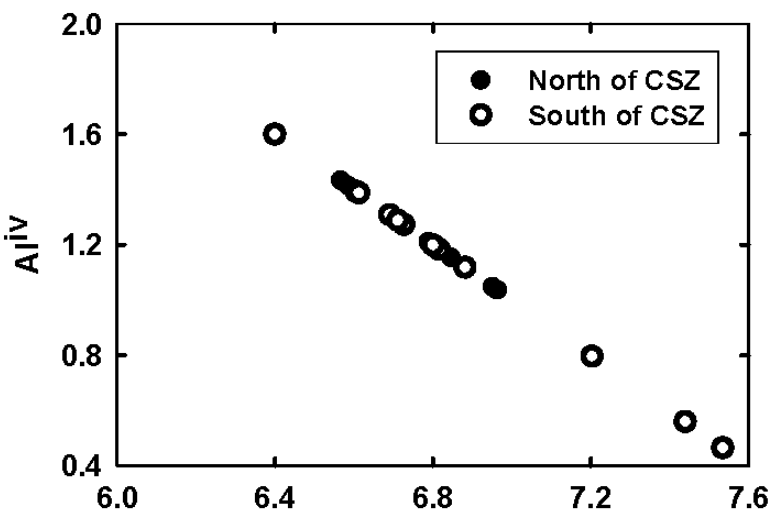

(a)

Si

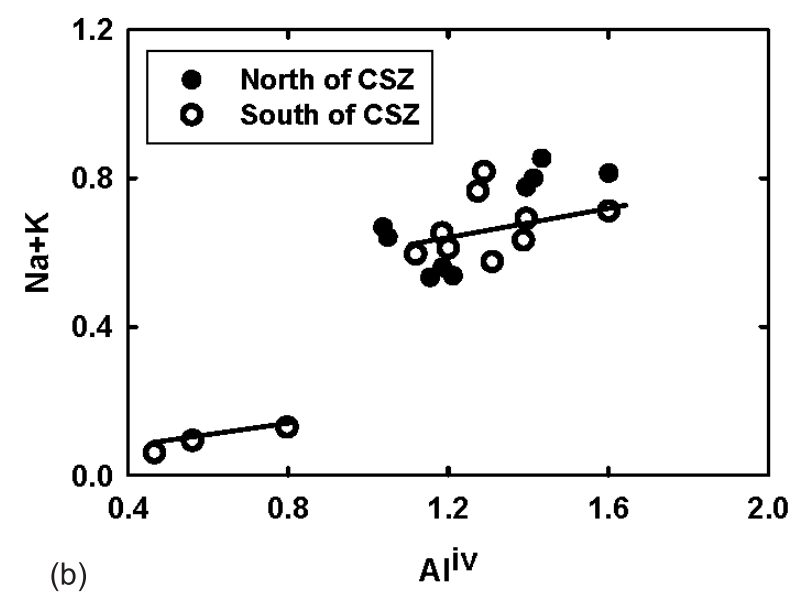

Figure 6. (a) $\mathrm{Al}^{\text {iv }}$ vs. Si plotted for amphiboles from north and south of the Cauvery Shear Zone. All amphiboles analyzed show a very good negative correlation between $\mathrm{Al}^{\text {iv }}$ and $\mathrm{Si}$ indicating $\mathrm{Al}$ substitution for Si. (b) The southern samples show a positive correlation in the plot $(\mathrm{Na}+\mathrm{K})$ vs. $\mathrm{Al}^{\mathrm{iv}}$ indicating coupled substitution involving these alkali cations and $\mathrm{Al}^{3+}$ for $\mathrm{Si}^{4+}$.

indicating coupled substitution of these cations for $\mathrm{Si}^{\text {iv }}$ (figure $6 \mathrm{~b}$ ). Thus it is inferred that compared to the northern part, the southern part has evolved in a fluid rich metamorphic environment as indicated by extensive $\mathrm{Na}$ and $\mathrm{K}$ substitution in amphibole.

On both sides of CSZ clinopyroxenes are diopsidic in composition while orthopyroxenes are composed of subequal amounts of enstatite and ferrosilite components.

\section{Pressure and temperature estimation}

\subsection{Using conventional geothermobarometry}

Pressure and temperature of the samples have been calculated using different models and these give a wide range of temperature and pressure estimates for any given sample. For example the temperature 
Table 2. Temperature $\left({ }^{\circ} \mathrm{C}\right)$ and pressure (kbar) estimated using conventional geothermobarometry.

\begin{tabular}{|c|c|c|c|c|c|c|c|c|c|c|c|c|c|c|c|}
\hline \multirow{3}{*}{$\begin{array}{l}\text { Model } \\
\text { Sample no. } \\
\text { Core } \backslash \text { Rim }\end{array}$} & \multicolumn{6}{|c|}{ South of CSZ } & \multicolumn{9}{|c|}{ North of CSZ } \\
\hline & \multicolumn{2}{|c|}{ S39 } & \multicolumn{2}{|c|}{ S37 } & \multicolumn{2}{|c|}{ S75 } & \multicolumn{3}{|c|}{ N3 } & \multicolumn{2}{|c|}{ N128 } & \multicolumn{3}{|c|}{$\mathrm{N} 28$} & \multirow{2}{*}{$\begin{array}{c}\mathrm{N} 38 \\
\mathrm{C}\end{array}$} \\
\hline & $\mathrm{C}$ & $\mathrm{R}$ & $\mathrm{C}$ & $\mathrm{R}$ & $\mathrm{C}$ & $\mathrm{R}$ & $\mathrm{C}$ & $\mathrm{R}$ & Symp. & $\mathrm{C}$ & $\mathrm{R}$ & $\mathrm{C}$ & $\mathrm{R}$ & Corona & \\
\hline $\begin{array}{l}\text { grt-cpx (temp. in } \\
\left.{ }^{\circ} \mathrm{C}\right) \text { Pattison and } \\
\text { Newton }(1989) \\
(8 \text { kbar })\end{array}$ & 664 & 558 & 840 & 765 & 610 & 599 & 648 & 535 & 609 & 670 & 728 & 575 & 593 & 565 & 715 \\
\hline $\begin{array}{l}\text { Ellis and Green } \\
(1979)\end{array}$ & 754 & 689 & 909 & 855 & 726 & 719 & 864 & 776 & 834 & 881 & 916 & 713 & 726 & 722 & 796 \\
\hline $\begin{array}{l}\text { grt-cpx-pl-qtz } \\
\text { (pressure in } \\
\text { kbar) Eckert } \\
(1991)\left(800^{\circ} \mathrm{C}\right)\end{array}$ & 7.3 & 6.9 & 9.2 & 8.7 & 6.2 & 6.2 & 7.4 & 7.82 & 11 & 9 & 9.2 & 7.3 & 7.1 & 8.4 & 9.1 \\
\hline $\begin{array}{l}\text { Newton and } \\
\text { Perkins }(1982) \\
\left(800^{\circ} \mathrm{C}\right)\end{array}$ & 5.6 & 5.2 & 7.5 & 7 & 4.6 & 4.4 & 5.7 & 6.09 & 8.9 & 7.2 & 7.4 & 5.6 & 5.4 & 6.7 & 7.4 \\
\hline
\end{tabular}

$\mathbf{C}=$ Core $\mathbf{R}=$ Rim; Symp. $=$ Symplectite.

estimate for sample $\mathrm{N} 3$ (core) ranges from $864^{\circ} \mathrm{C}$ to $639^{\circ} \mathrm{C}$ using different models of Grt-Cpx equilibrium. Hence we have used selected models and our choice of geothermobarometers is based on those calibrations relying on

- well constrained calorimetric data or an extensive dataset of experimental phase equilibrium, and

- composition of minerals in the experimental run products are comparable to the mineral composition found in the mafic granulites of the Namakkal area.

Based on the above criteria, Grt-Cpx equilibria given by Pattison and Newton (1989) and GrtCpx-Pl-Qtz equilibria of Eckert et al (1991) are best suited for estimation of temperature and pressure, respectively, for the mafic granulites of the Namakkal area. The assemblages Grt-Cpx (for temperature) and Grt-Cpx-Pl-Qtz (for pressure) are found in the mafic granulites occurring on either side of the CSZ in the Namakkal area. The estimated temperature and pressure based on these equilibria are given in table 2 .

Metamorphic temperatures have been estimated assuming that the pressure was $8 \mathrm{kbar}$ for all samples to facilitate intercomparison. Similarly pressure has been calculated at a temperature of $800^{\circ} \mathrm{C}$ (table 2). Sample \#S37 from the southern part shows a maximum temperature of $840^{\circ} \mathrm{C}$ pressure of $9.2 \mathrm{kbar}$, samples from both northern and southern parts have recorded a maximum pressure of 9.2 kbar. Hence it can be assumed that the southern part of the shear zone has suffered a higher temperature metamorphism in comparison to the northern part.
Metamorphic temperature can be also calculated using the estimated pressure values (table 2) instead of an assumed value in the appropriate model for geothermometry. Similarly pressure can be estimated using the above derived temperature values in the relevant geobarometric equations. Metamorphic temperatures and pressures thus estimated for the granulite samples from the Namakkal area are given in table 3. These temperature and pressure estimates are potentially closer to the equilibrium values and will be useful in inferring the $\mathrm{P}-\mathrm{T}$ trajectory (figure 7 ).

\subsection{Using TWEEQU program}

Using the TWEEQ (Ver. 202) program of Berman $(1988,1991)$ plots of reaction lines have been made for the samples analyzed by EPMA. The mineral assemblages used for calculating and plotting the reaction curves are garnet, clinopyroxene, orthopyroxene and plagioclase. For all samples the reaction lines intersect at several points and therefore do not give any meaningful $\mathrm{P}-\mathrm{T}$ information. It is possible that

- all minerals have not equilibrated simultaneously at peak metamorphic conditions in these samples,

- due to retrogression some of the mineral compositions have been altered and,

- the mineral assemblage may not represent a single metamorphic event.

However, from the textural studies, the samples from the south of the Cauvery Shear Zone appear to represent a single metamorphic event and least altered. Hence it is suggested that in these 
Table 3. Temperature $\left({ }^{\circ} \mathrm{C}\right)$ and pressure (kbar) estimated by solving respective geothermometer and geobarometer equations iteratively using calculated values of temperature and pressure given in table 2.

\begin{tabular}{|c|c|c|c|c|c|c|c|c|c|c|c|c|c|c|c|}
\hline \multirow{3}{*}{$\begin{array}{l}\text { Model } \\
\text { Sample no. } \\
\text { Core } \backslash \text { Rim }\end{array}$} & \multicolumn{6}{|c|}{ South of CSZ } & \multicolumn{9}{|c|}{ North of CSZ } \\
\hline & \multicolumn{2}{|c|}{ S39 } & \multicolumn{2}{|c|}{ S37 } & \multicolumn{2}{|c|}{$\mathrm{S} 75$} & \multicolumn{3}{|c|}{ N3 } & \multicolumn{2}{|c|}{ N128 } & \multicolumn{3}{|c|}{ N28 } & \multirow{2}{*}{$\begin{array}{c}\text { N38 } \\
\text { C }\end{array}$} \\
\hline & $\mathrm{C}$ & $\mathrm{R}$ & $\mathrm{C}$ & $\mathrm{R}$ & $\mathrm{C}$ & $\mathrm{R}$ & $\mathrm{C}$ & $\mathrm{R}$ & Symp. & $\mathrm{C}$ & $\mathrm{R}$ & $\mathrm{C}$ & $\mathrm{R}$ & Corona & \\
\hline $\begin{array}{l}\text { grt-cpx (temp. in } \\
\left.{ }^{\circ} \mathrm{C}\right) \text { Pattison and } \\
\text { Newton }(1989)\end{array}$ & 656 & 545 & 849 & 768 & 595 & 583 & 639 & 524 & 614 & 670 & 731 & 563 & 581 & 558 & 717 \\
\hline $\begin{array}{l}\text { grt-cpx-pl-qtz } \\
\text { (pressure in kbar) } \\
\text { Eckert }(1991)\end{array}$ & 6.5 & 5.5 & 9.6 & 8.5 & 5.3 & 5.2 & 6.4 & 6.02 & 8.8 & 7.9 & 8.6 & 5.9 & 5.9 & 6.7 & 8.4 \\
\hline
\end{tabular}

$\mathbf{C}=$ Core $\mathbf{R}=$ Rim; Symp. = Symplectite.

samples minerals like plagioclase and garnet have not reached equilibrium during retrogression due to lower diffusion rates in these minerals.

\subsection{Retrograde $P-T$ trajectories}

$\mathrm{P}-\mathrm{T}$ trajectories for six samples (three each from the north and south of CSZ) have been constructed and shown in figure 7 . Peak temperature and pressure of northern and southern parts are $731^{\circ} \mathrm{C}$; $8.6 \mathrm{kbar}$ and $849^{\circ} \mathrm{C}$ and $9.6 \mathrm{kbar}$ respectively (table 3).

$\mathrm{dP} / \mathrm{dT}$ values vary from 3 to 14 (bar $/{ }^{\circ} \mathrm{C}$ ) when all the samples are considered. Southern samples have maximum slope in the $\mathrm{P}-\mathrm{T}-\mathrm{t}$ space. It is indicative of a change in pressure at more isothermal conditions for the area occurring to the south of CSZ compared to the northern one.

In the southern part samples S37 and S39 have more or less parallel $\mathrm{P}-\mathrm{T}$ trajectories which may indicate similar uplift rates. Northern samples N128 and N3 have different slopes and could indicate a more complex metamorphic evolution of this terrane.

Symplectite and corona of Grt-Cpx-Plag-Qtz the assemblage present in northern samples N3 and N28, are also used to calculate pressure and temperature. In general, during the uplift of metamorphic rocks symplectite and corona are expected to equilibrate at a lower temperature and pressure than the core. The above samples give a significantly higher pressure for the symplectite and corona than the core and rim even at comparatively similar temperatures. This could indicate tectonic stacking/thrusting (or accretion) of continental crust, which might have increased the pressure without changing the temperature. Because, during tectonic stacking the increase in pressure would be instantaneous, whereas, the geothermal gradient approaches equilibrium after about $20 \mathrm{Ma}$ (Philpotts 1990) and the rate of heat flow by

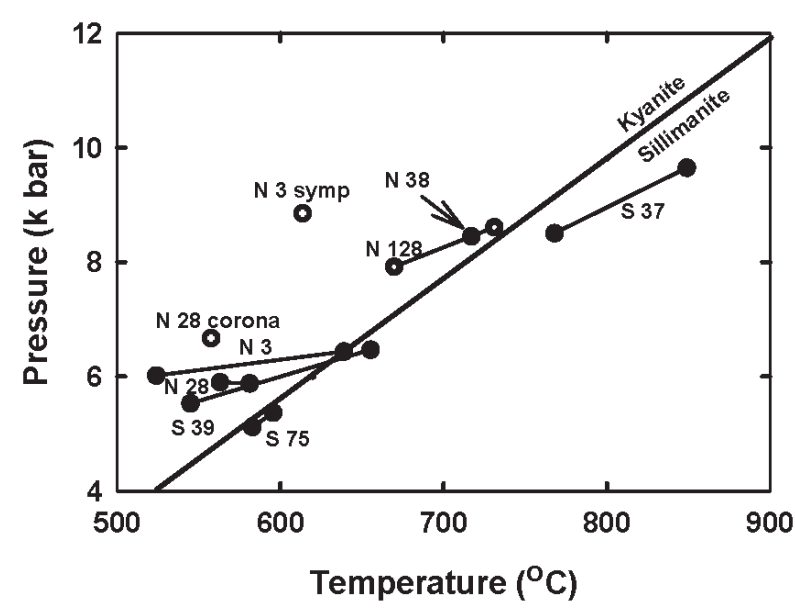

Figure 7. $\mathrm{P}-\mathrm{T}$ trajectories for three samples each from north and south of CSZ. The southern samples S37 and S39 have more or less parallel $\mathrm{P}-\mathrm{T}$ trajectories, which may indicate similar uplift rates. Note that pressure estimates for symplectite and corona on northern samples N3 and N28 are much higher than their respective core and rim.

conduction would be a slow process. This type of tectonic process could give rise to an isobaric cooling path or anticlockwise path for the metamorphic terrain (Bohlen 1987; Ellis 1987). Sample \#N128 from the northern part also shows higher pressure and temperature estimates for the rim than the core. Thus, it is likely that the metamorphic terrain occurring to the north of CSZ could have been affected by tectonic stacking/thrusting during its evolution.

\section{Discussion}

The $\mathrm{P}-\mathrm{T}$ estimates and trajectories obtained in the mafic granulites occurring to the south of CSZ (table 3) are comparable to that of the Ganguvarpatti rocks occurring $200 \mathrm{~km}$ south of Namakkal, near Madurai. Near-peak metamorphic conditions of $800^{\circ} \mathrm{C}$ and $8 \mathrm{kbar}$ have been observed 
from the sapphirine-bearing granulites of Ganguvarpatti (Mohan and Windley 1993; Mohan et al 1996). Garnetiferous mafic granulites and metapelites from Palghat gap also give a similar pressure temperature range of 9-10 kbar and 800 $900^{\circ} \mathrm{C}$ (Ravindrakumar and Chacko 1994) during an isothermal clockwise decompression (ITD) path. For all these terrains occurring south of CSZ (Namakkal, Ganguvarpatti and Palghat), not only comparable peak metamorphic pressure and temperature, but also, similar isothermal decompressional paths have been reported. These terrains might have been affected by the same regional scale metamorphic event. On this basis it is suggested that the granulite terrain occurring south of CSZ extends up to the Madurai and Palghat areas.

Near peak metamorphic conditions of $10.2 \mathrm{kbar}$ and $900^{\circ} \mathrm{C}$ (Raith et al 1990; Srikantappa et al 1992) are reported from the granulite terrane of Nilgiri which predominantly comprised of enderbitic granulites and pyroxenite and gabbro (Janardhan et al 1982; Janardhan 1999a). Coorg granulites record near peak metamorphic conditions of 550 to $750^{\circ} \mathrm{C}$ at pressures of 4.5 to $8.6 \mathrm{kbar}$ (Srikantappa et al 1994; Devaraju and Janardhan 2004). The $\mathrm{P}-\mathrm{T}$ path of the northern granulite block is generally anticlockwise (Raith et al 1990) and can be stated to be made up of two components, an earlier IBC with a slightly later ITD (Janardhan and Shankara 1995; Janardhan 1999a). P-T estimates and trajectory acquired for the mafic granulites occurring to the north of CSZ is comparable to that of the rocks from Nilgiri and B-R hills and Coorg. It is postulated that granulite terrane found to the north of CSZ had similar metamorphic evolution involving multiple stages, as that of the northern granulites.

Rocks of the Moyar Shear Zone occurring north of the Nilgiri block have been given $\mathrm{Rb}-\mathrm{Sr}$ biotite age of $2300 \mathrm{Ma}$ (Jayananda and Peucat 1996). Peucat et al (1989) have determined $\mathrm{Pb}-\mathrm{Pb}$ whole rock isochron age of $2578 \pm 63 \mathrm{Ma}$ for charnockites of Nilgiri which is indistinguishable from that of zircon $\mathrm{Pb}-\mathrm{Pb}$ age of $2535 \mathrm{Ma}$ on similar Nilgiri rocks determined by Bhul (1987). Wholerock$\mathrm{Sm} / \mathrm{Nd}$ isochrons for several comagmatic rocks of the layered meta-anorthosite complexes of Sittampundi and Bhavani (that occur as tectonic lenses within CSZ) yield concordant ages of $2935 \pm$ $60 \mathrm{Ma}, \epsilon_{\mathrm{Nd}}+1.85 \pm 0.16$ and $2899 \pm 28 \mathrm{Ma}, \epsilon_{\mathrm{Nd}}+$ $2.18 \pm 0.14$ respectively (Bhaskar Rao et al 1996). Mei $\beta$ ner et al (2002) have suggested that the rocks of Moyar, Bhavani and Palghat Shear Zones have been affected by Neoproterozoic (600-490 Ma) metamorphism on the basis of $\mathrm{Sm}-\mathrm{Nd}$ and $\mathrm{Rb}-\mathrm{Sr}$ isotope studies.

On the rocks of Madurai Block, Jayananda and Peucat (1995) have reported $\mathrm{Pb}$ evaporation ages of $2115 \pm 8 \mathrm{Ma}$ and $1858 \pm 31 \mathrm{Ma}$ for the core and rim of Zircon found in charnockite from Kodaikanal hill. Bartlett et al (1995) obtained $\mathrm{Pb}$ evaporation age of $2436 \pm 4 \mathrm{Ma}$ and $547 \mathrm{Ma}$ for granite occurring east of the Kodaikanal hills. In both cases, the older dates have been attributed to the age of the protolith and the younger dates as the age of metamorphism or crustal mobilization. Pb evaporation technique on single zircons from charnockite of Oddanchatram intrusive complex gives an age of $652-560 \mathrm{Ma}$ and $\mathrm{Sm}-\mathrm{Nd}$ age of $553 \pm 15 \mathrm{Ma}$ using garnet-wholerock isochron method (Jayananda and Peucat 1996). Bartlett et al (1995) have reported $547 \pm 14 \mathrm{Ma}$ as the age of Zircon overgrowth in charnockite for the Madurai area. Hansen et al (1985) have reported an age of $550 \pm 15 \mathrm{Ma}$ using $\mathrm{Rb}-\mathrm{Sr}$ whole rock method and $\mathrm{Rb}-\mathrm{Sr}$ biotite cooling age of $425 \pm 55 \mathrm{Ma}$ for Madurai gneisses.

From the available geochronological information it is evident that the ages of crystallization and metamorphism of rocks occurring to the north of CSZ are $2500 \mathrm{Ma}$ or older. The $550 \mathrm{Ma}$ old PanAfrican igneous activity is not yet reported from this northern granulite terrane. Also ages older than $2436 \pm 4$ Ma have not been reported for the southern granulite terrane, where $550 \mathrm{Ma}$ old granite intrusions are extensively found. In both the terrains ca 1000 Ma old either igneous or metamorphic event has not been reported unlike in certain segments of the Eastern Ghats belt (Mezger and Cosca 1999).

Windley et al (1994) suggested that the N-S trending dextral Tana Shear Zone passing through central Madagascar extends into India as the Palghat-Cauvery Shear Zone. Bhaskar Rao et al (1996) considered that this shear zone may further extend into Antarctica separating Napier complex and Rayner complex. However, the Rayner complex consists of $1500 \mathrm{Ma}$ and $960 \mathrm{Ma}$ old rocks whereas, the granulite terrane south of the Palghat-Cauvery Shear Zone is made up of predominantly ca. 2000 and $550 \mathrm{Ma}$ old rocks. It is likely that the extension of the Palghat-Cauvery Shear Zone into Antarctica separates Rayner complex and Lutzow-Holm complex. The LutzowHolm complex consists of $550 \mathrm{Ma}$ old rocks similar in age, to the granulites occurring south of the Palghat-Cauvery Shear Zone. However, the available geochronological information on the rocks found on either side of the Palghat-Cauvery Shear Zone is scanty for any meaningful correlation.

\section{Conclusion}

Textural and geothermobarometric determinations of mafic granulites occurring on either side of the Cauvery Shear Zone in the present study 
area indicate that the northern block has undergone more complex metamorphic evolutionary history evidenced by isobaric cooling and isothermal decompression. On the other hand, mafic granulites of the southern block preserve evidences of their metamorphic evolution through the isothermal decompression path. The mafic granulites of the northern block have been subjected to peak metamorphic temperature and pressure conditions of $670^{\circ} \mathrm{C}$ and $7.9 \mathrm{kbar}$ and 731 at $8.6 \mathrm{kbar}$ on the basis of the core and rim analysis. The mafic granulites of the southern block have recorded higher peak metamorphic temperature and pressure conditions of $849^{\circ} \mathrm{C}$ and $9.6 \mathrm{kbar}$. Contrasting metamorphic evolutionary histories inferred for the mafic granulites occurring north and south of the Cauvery Shear Zone in the Namakkal area make us suggest that the CSZ could represent a paleosuture between two continental blocks with distinct metamorphic evolutionary histories. Detailed thermochronometric studies are required for a better understanding of the crustal evolution in the southern granulite terrane.

\section{Acknowledgements}

The authors are thankful to the Department of Geology, Mysore University for extending EPMA facilities and particularly, Dr. B Basavalingu's help in this regard is gratefully acknowledged. We thank the reviewer whose detailed comments and suggestions have been very helpful in revising the manuscript. The senior author was financially supported by a UGC-Junior Research Fellowship.

\section{References}

Bartlett J M, Harris N B W, Hawkesworth C J and Santosh M 1995 New isotope constraints on the crustal evolution of southern India and Pan-African granulite metamorphism. In: India and Antarctica during Precambrian; Mem. Geol. Soc. India 34 391-397.

Berman R G 1988 Internally-consistent thermodynamic data for the minerals in the system $\mathrm{K}_{2} \mathrm{O}-\mathrm{Na}_{2} \mathrm{O}-\mathrm{CaO}-$ $\mathrm{MgO}-\mathrm{FeO}-\mathrm{Fe}_{2} \mathrm{O}_{3}-\mathrm{Al}_{2} \mathrm{O}_{3}-\mathrm{SiO}_{2}-\mathrm{TiO}_{2}-\mathrm{H}_{2} \mathrm{O}-\mathrm{CO}_{2} ;$ J. Petrol. $29445-522$.

Berman R G 1991 Thermobarometry using multiequilibrium calculation: a new technique, with petrological application; Can. Mineral. 29 833-855.

Bhadra B K 1999 Phyllonite from Attur shear zone and its tectonic significance in Southern Granulite Terrain; Curr. Sci. 77 1685-1687.

Bhaskara Rao Y J, Chetty T R K, Janardhan A S and Gopalan K 1996 Sm-Nd and Rb-Sr ages and P-T history of Archean Sittampundi and Bhavani layered metaanorthosite complexes in Cauvery Shear Zone, South India: evidences for Neoproterozoic reworking of Archean crust; Contrib. Mineral. Petrol. 125 237-250.
Bhul D 1987 U-Pb und Rb-Sr Altersbestimmungen und Untersuchngen zum Strontium-isotopenaustausch an Granulitien Sudindiens. PhD thesis, University of Munster, Germany.

Bohlen S R 1987 Pressure-temperature-time paths and a tectonic model for the evolution of granulites; J. Geol. 95 617-632.

Chetty T R K 1996 Proterozoic Shear Zone in Southern Granulite terrain, India. In: The Archean and Proterozoc terrain in Southern India East Gondwana; (eds) Santosh M and Yoshida M, Gondwana Research Group Memoir 3 77-89.

Devaraju J and Janardhan A S 2004 Metamorphic history of staurolite-kyanite-garnet-cordierite bearing pelites of Mangalore-Mercara lineament, South India; J. Geol. Soc. India 63 555-561.

Drury S A, Harris N B W, Holt R W and Reeves-Smith G J 1984 Precambrian tectonics and crustal evolution in South India; J. Geol. 92 3-20.

Eckert J O, Newton R C and Kleppa O J 1991 The $\Delta \mathrm{H}$ of reaction and recalibration of garnet-pyroxeneplagioclase-quartz geobarometers in the CMAS system by solution calorimetry; Am. Mineral. 76 148-160.

Ellis D J 1987 Origin and evolution of granulites in normal and thickened crusts; Geology 15 167-170.

Ellis D J and Green D H 1979 An experimental study of the effect of $\mathrm{Ca}$ upon garnet-pyroxene $\mathrm{Fe}-\mathrm{Mg}$ exchange equilibria; Contrib. Mineral. Petrol. 71 13-22.

Frost B R and Chacko T 1989 The granulite uncertainity principle: limitations on thermobarometry in granulites; J. Geol. 97 435-450.

Ghosh J G 1997 Structural and geochronologic study along parts of Palghat-Cauvery shear zone, S. India; (eds) Cox R M and Aswal L D Gondawana Research Group Misc. Publ. Osaka, Pp. 21-23.

Hansen E C, Hickman M H, Grant N K and Newton R C 1985 Pan-African age of Peninsular gneiss near Madurai, South India; EOS 66 419-420.

Harley S L 1989 The origin of granulites: A metamorphic perspective; Geol. Mag. 126 215-247.

Janardhan A S 1999a Evolution of granulite facies charnockites of southern India; In: Proceedings of the International Symposium on Charnockite and Granulite Facies Rocks, (eds) Murthy N G K and Ram Mohan, Department of Geology, Madras University, Chennai 4 15-26.

Janardhan A S 1999b Southern Granulite terrain, South of Palghat-Cauvery Shear Zone: Implication for India-Madagascar connection; Gondwana Research 2 463-469.

Janardhan A S and Shankara M A 1995 Pressuretemperature estimation and tectonic implication of cordierite bearing assemblages from the amphibolite to granulite facies tract of S. Karnataka; Ind. Mineral. 29 60-73.

Janardhan A S, Francis Anto K and Sivasubramanian P 1996 Evolution of the Proterozoic southern granulite terrain: Its position in eastern Gondwana; Gondwana Research Group Misc. Publ. 4 38-39.

Janardhan A S, Newton R C and Hansen E C 1982 The transformation of amphibolite gneiss to charnockite in southern Karnataka and northern Tamil Nadu, India; Contrib. Mineral. Petrol. 96 225-244.

Janardhan A S, Jayananda M and Shankara M A 1994 Formation and tectonic evolution of granulites from the Biligirirangam and Nilgiri Hills, S. India: Geochemical and isotopic constraints; J. Geol. Soc. India 44 27-40.

Jayananda M and Peucat J J 1995 Archaean crust formation in southern India: geochronologic and isotopic constraints. In: India as a fragment of east Gondwana; (eds) 
Yoshida M, Santosh M and Rao A T, Gondwana Research Group Memoir 2 15-21.

Jayananda M and Peucat J J 1996 Geochronological frame work of southern India. In: The Archaean and Proterozoic terranes of Southern India within east Gondwana; (eds) Santosh M and Yoshida M, Gondwana Research Group Memoir 3 53-75.

McWilliams M O 1981 Paleomagnetism and Precambrian tectonic evolution. In: Precambrian Plate Tectonics; (ed.) Kroner A, Amsterdam: Elsevier, Pp. 649-687.

Mei $\beta$ ner B, Deters P, Srikantappa C and Kohler H 2002 Geochronological evolution of the Moyar, Bhavani and Palghat shear zones of southern India: Implication of east Gondwana correlations; Precamb. Res. 114 149-175.

Mengel F and Rivers T 1991 Decompressional reactions and $\mathrm{P}-\mathrm{T}$ conditions in high-grade rocks, northern Labrador: $\mathrm{P}-\mathrm{T}-\mathrm{t}$ paths from individual samples and implications for early proterzoic tectonic evolution; J. Petrol. 32 139-167.

Mezger K and Cosca M A 1999 The thermal history of the Eastern Ghats Belt (India) as revealed by $\mathrm{U}-\mathrm{Pb}$ and ${ }^{40} \mathrm{Ar} /{ }^{39} \mathrm{Ar}$ dating of metamorphic and magmatic minerals: implications for the SWEAT correlation; Precamb. Res. 94 251-271.

Mohan A and Windley B F 1993 Crustal trajectory of sapphirine-bearing granulites from Ganguvarpatti, South India: evidence for an isothermal decompression path; J. Met. Geol. 11 867-878.

Mohan A, Prakash D and Motoyoshi Y 1996 Decompressional $\mathrm{P}-\mathrm{T}$ history in sapphirine-bearing granulites from Kodaikanal, southern India. J. South East Asian Earth Sci. 14 231-243.

Mukhopadhyay D, Senthil Kumar P, Srinivasan R, Bhattacharya T and Sengupta P 2000 TectonoMetamorphic pattern in the eastern sector of the Palghat-Cauvery lineament; Ind. Mineral. 34 20-21.

Newton R C and Perkins D 1982 Thermodynamic calibration of geobarometer. In: Thermodynamic of minerals and melt; New York: Springer, Pp. 129-145.

Passchier C W and Trouw R A J 1996 Microtectonics Springer-Verlag, Berlin, Germany, p. 289.

Pattison D R M and Newton R C 1989 Reversed experimental calibration of the garnet-clinopyroxene $\mathrm{Fe}-\mathrm{Mg}$ exchange thermometer; Contrib. Mineral. Petrol. 101 87-103.
Peucat J J, Videl P, Bernad-Griffiths J and Condie K C $1989 \mathrm{Sr}, \mathrm{Nd}$ and $\mathrm{Pb}$ isotopic systematics in the Archean low-to high-grade transition zone of southern India: syn-accretion vs. post accretion granulites; J. Geol. 97 537-550.

Philpotts A R 1990 Principles of Igneous and Metamorphic Petrology Prentice-Hall International, p. 498.

Raith M, Karmakar, Srikantappa C, Ashamanjari K G and Spiering B 1990 The granulite terrane of the Nilgiri Hills (South India). In: Granulites and crustal evolution; (eds) Viezeuf D and Vidal P, Kluwer Publ. Pp. 339-365.

Ravindrakumar G R and Chacko T 1994 Geothermobarometry of mafic granulites and metapelite from the Palghat gap, South India: petrological evidence for isothermal uplift and rapid cooling; J. Met. Geol. 12 479-492.

Srikantappa C 1996 The Nilgiri granulites. In: The Archaean and Proterozoic terrain in Southern India within East Gondwana; (eds) Santhosh M and Yoshida M, Gondwana Research Group Memoir 3 185-222.

Srikantappa C, Ashamanjari K G and Raith M 1988 Petrology and geochemistry of the high pressure Nilgiri granulite terrane, South India; J. Geol. Soc. India $\mathbf{3 1}$ $147-148$.

Srikantappa C, Raith M and Tourtet J L R 1992 Synmetamorphic high density carbonic fluids in the lower crust: evidence from the Nilgiri Granulites, S. India; J. Petrol. 28 803-834.

Srikantappa C, Venugopal L, Devaraju J and Basavalingu B 1994 P-T conditions of metamorphism and fluid inclusion characteristics of the Coorg Granulites, Karnataka; J. Geol. Soc. India 44 495-504.

Unrug R 1996 The assembly of Gondwanaland; Episodes 19 $11-20$.

Weibe R A and Janardhan A S 1988 Metamorphism of the Oddanchatram anorthosite, Tamil Nadu, South India; Abst Indo-US Workshop on the Deep Continental Crust of South India, Bangalore; Pp. 163-165.

Windley B F, Razafiniparany A, Razakamanana $\mathrm{T}$ and Ackermand D 1994 Tectonic framework of the Precambrian of Madagascar and its Gondwana connections: A review and reappraisal; Geol. Rund. 83 642-659.

Yoshida M, Rajesh H M and Santosh M 1999 Juxtaposition of India and Madagascar: A perspective; Gondwana Research 2 449-462. 